\title{
Planting Alfalfa with Cover Crops on Forage Dry Matter Yield and Nutritive Values of Alfalfa
}

\author{
Doohong Min \& Iryna McDonald \\ 1712 Claflin Road, 2004 Throckmoron Hall, \\ Department of Agronomy, Kansas State University, Manhattan, KS 66506 \\ Email:dmin@ksu.edu \\ Accepted: April 15, 2017 Published: June 16, 2017 \\ URL: https://doi.org/10.5296/jas.v5i2.11408
}

Received: March 18, 2017

doi:10.5296/jas.v5i2.11408

\begin{abstract}
The objective of this study was to evaluate the effect of planting alfalfa (Medicago sativa L.) with- and without cover crops on forage dry matter yield and nutritive values of alfalfa in Kansas, USA. In the first production year 2014, dry matter yield of mono-culture alfalfa appears to be compatible or even higher than planting with certain species of winter annual forages as a cover crop. Alfalfa planted with a combination of four different multi-species winter annual forages such as oats (Avena sativa L.), oilseed radish (Raphanus sativus L.), annual ryegrass (Lolium multiflorum L.), and turnip (Brassica rapa L.) had the highest dry matter yield of alfalfa in 2014. Dry matter yield of alfalfa in $2^{\text {nd }}$ production year 2015 was similar to alfalfa + oats and alfalfa + oats + oilseed radish + annual ryegrass + turnip or significantly higher than alfalfa planted with annual ryegrass, oilseed radish, and turnip together. Based on two year of data in 2014 and 2015, the highest alfalfa yield occurred when alfalfa was planted with a combination of oats, oilseed radish, annual ryegrass, and turnip. The lowest dry matter yield of alfalfa occurred when alfalfa was planted with annual ryegrass. No significant differences in crude protein (CP), acid detergent fiber (ADF), and neutral detergent fiber (NDF) were found when comparing alfalfa monoculture with alfalfa + oats, alfalfa + oilseed radish, alfalfa + oats + oilseed radish + annual ryegrass + turnip, and alfalfa + turnip treatments. When considering both dry matter and nutritive values of alfalfa, planting alfalfa with cover crops appears to be compatible or better practice than planting alfalfa monoculture.
\end{abstract}

Keywords: Alfalfa, Cover Crop, Forage, Dry Matter Yield, Nutritive Values 


\section{Introduction}

Alfalfa is called "Queen of Forages" as one of the most important forage cash crops that is produced more than $70 \%$ of the alfalfa in State of Kansas, USA (USDA, 2012). Alfalfa is also a very important forage to the dairy and beef industry in Kansas. Alfalfa is commonly harvested 4 - 5 times yearly in Southwest Kansas under irrigation system, and proper alfalfa production including plant method is important to profitable alfalfa hay production, particularly in the optimizing dry matter yield and nutritive values. It is common that most alfalfa is planted in spring time due to better moisture condition in the soil than in the fall but there might be more weed competition in spring planting than in fall planting. That's why some producers plant alfalfa in late summer or early fall in Kansas. It is not, however, uncertain that planting alfalfa with cover crops is desirable practice to alfalfa yield and nutritive values. Many reports indicate that cover crops can increase crop yield and improve soil carbon and nitrogen, soil health, water quality, organic matter, nitrogen recovery, and as a weed control tool (Holderbaum et al., 1990; Meissinger et al., 1991; Komatsuzaki and Wagger, 2015; Thorup-Kristensen and Rasmussen, 2015; Sainju et al., 2015; Masilionyte et al., 2017; Mitchell et al., 2017). Planting alfalfa with cover crops might help establish good stands alfalfa where water is limited and improve dry matter yield and nutritive values of alfalfa as compared to planting alfalfa only. In contrast planting alfalfa with annual cover crops, alfalfa was also overseeded into warm-season perennials such as switchgrass stands. Forage quality of alfalfa-switchgrass binary mixture was significantly higher than in pure switchgrass stands (Mantino et al., 2016). Although the information on planting alfalfa with oats as cover crop is available mostly as extension bulletins (Lanini et al., 1992; Dixon et al., 2005, Undersander et al., 2010), very limited number of scientific research papers are available focusing on planting alfalfa with cover crops in the USA. Thus, the objective of this study was to evaluate the effect of planting alfalfa with different cover crops on forage dry matter yield and nutritive values of alfalfa in Southwest Kansas in USA.

\section{Materials and Methods}

This alfalfa-cover crop research was conducted at the Kansas State University Southwest Research-Extension Center, Garden City $\left(37^{\circ} 58^{\prime} 31^{\prime \prime} \mathrm{N}, 100^{\circ} 51^{\prime} 51^{\prime \prime} \mathrm{W}\right)$ in Kansas, USA. The weather information during growing seasons in 2014, 2015, and 30 year average are shown in Table 1. On average, there was higher rainfall in 2014 than that of 2015 and it was a little warmer in 2015 than that of 2014 in Garden City, KS. During summer months, year 2014 was wetter than year 2015 .

Table 1. Monthly 30-year temperature and precipitation averages and departures from average for 2014 an 2015 in Garden City, KS.

\begin{tabular}{|l|c|r|r|r|}
\hline \multicolumn{5}{|c|}{ 30-Year Departure from average } \\
\hline Item & Month & Average & 2014 & 2015 \\
\hline
\end{tabular}




\begin{tabular}{|c|c|c|c|c|}
\hline \multirow[t]{8}{*}{ Temperature, ${ }^{\circ} \mathrm{C}$} & March & 14.2 & -1.8 & +3.1 \\
\hline & April & 19.6 & +0.2 & +2.3 \\
\hline & May & 24.7 & +0.2 & -2.3 \\
\hline & June & 30.3 & +0.6 & +4.2 \\
\hline & July & 33.4 & +0.9 & +0.7 \\
\hline & August & 32.2 & +1.1 & +6.9 \\
\hline & September & 28.0 & +0.7 & +4.4 \\
\hline & October & 21.1 & +2.2 & +2.6 \\
\hline \multirow[t]{8}{*}{ Precipitation, mm } & March & 31.24 & -24.89 & -23.11 \\
\hline & April & 44.20 & -26.67 & -33.02 \\
\hline & May & 76.20 & -60.20 & +85.85 \\
\hline & June & 78.74 & +187.96 & -43.43 \\
\hline & July & 71.12 & +25.65 & +65.02 \\
\hline & August & 63.75 & -13.21 & +18.54 \\
\hline & September & 36.07 & +32.77 & -34.29 \\
\hline & October & 30.99 & +14.22 & +41.91 \\
\hline
\end{tabular}




\section{Macrothink}

The soil type for the study was a deep, well drained Ulysses silt loam (fine-silty, mixed, mesic Aridic Haplustoll) and a soil pH was 8.4. Phosphorus and potassium were 40 and 820 ppm, respectively and the organic matter was $1.5 \%$. Alfalfa and cover crop seeds were drilled (20 cm row spacing) into a prepared firm seedbed on August 23, 2013. Treatments of alfalfa monoculture and alfalfa-cover crop include: 1) Alfalfa, 2) Alfalfa + Oats, 3) Alfalfa + Oilseed Radish, 4) Alfalfa + Oats + Oilseed Radish + Annual Ryegrass + Turnip, 5) Alfalfa + Annual Ryegrass, and 6) Alfalfa + Turnip. The plot size was $3.3 \mathrm{~m}$ x $3.3 \mathrm{~m}$ and alfalfa forage samples were harvested 4 times a year using a flail type forage harvester with leaving a $5-\mathrm{cm}$ stubble height in alfalfa. Sub-samples collected from the harvested forage materials were dried in forced-air ovens at $65{ }^{\circ} \mathrm{C}$ for 72 hours to determine dry matter content and calculate dry matter yield of alfalfa $(\mathrm{Mg} / \mathrm{ha})$.

After drying, samples were ground to pass a 1-mm Wiley mill screen. Nutritive values of ground forage samples were analyzed at the Kansas State University Forage Quality Analysis Lab. Forage quality measurements such as crude protein (CP and calculated as total nitrogen (\%) x 6.25), acid detergent fiber (ADF, consisting of cellulose and lignin, inversely correlated to potential digestibility), and neutral detergent fiber (NDF, consisting of hemicellulose, cellulose and lignin, inversely correlated with potential feed intake) were analyzed using a wet chemical analysis. The experimental design was randomized complete block with 4 replications. When the $F$-test was significant $(P<0.05)$, Fisher's protected LSD was used for multiple comparisons $(\alpha=0.05)$ (Steel and Torrie, 1980). Data on dry matter yield and nutritive values of alfalfa were collected and analyzed using PROC MIXED in SAS (SAS Institute, 2011).

\section{Results and Discussion}

In the first production year 2014, alfalfa yield ranged from 12.1 to $22.4 \mathrm{Mg} \mathrm{ha}^{-1}$ (Table 2). Dry matter yield of mono-culture alfalfa appears to be compatible or even higher than planting with certain species of winter annual forages as a cover crop. 


\section{Macrothink}

Table 2. Effects of Alfalfa Planted with Cover Crops on Dry Matter Yield of Alfalfa in 2014, 2015, and 2-Yr Totals.

\begin{tabular}{|l|r|r|r|}
\hline \multicolumn{1}{|c|}{ Treatments } & 2014 & 2015 & 2-Yr Totals \\
\hline \multicolumn{4}{|c|}{ Mg/ha } \\
\hline 1 & $18.9 \mathrm{c}$ & $18.3 \mathrm{~d}$ & $37.2 \mathrm{~d}$ \\
\hline 2 & $18.4 \mathrm{c}$ & $17.8 \mathrm{~cd}$ & $36.2 \mathrm{~d}$ \\
\hline 3 & $13.4 \mathrm{a}$ & $15.6 \mathrm{~b}$ & $28.9 \mathrm{~b}$ \\
\hline 4 & $22.4 \mathrm{~d}$ & $18.4 \mathrm{~d}$ & $40.8 \mathrm{e}$ \\
\hline 5 & $12.1 \mathrm{a}$ & $13.4 \mathrm{a}$ & $25.5 \mathrm{a}$ \\
\hline 6 & $16.3 \mathrm{~b}$ & $16.7 \mathrm{bc}$ & $33.0 \mathrm{c}$ \\
\hline
\end{tabular}

$\dagger$ Lower case letter within the same row denote statistical differences between different cover crop treatments $(\alpha=0.05)$.

‡ Treatments: 1) Alfalfa, 2) Alfalfa + Oats, 3) Alfalfa + Oilseed Radish, 4) Alfalfa + Oats + Oilseed Radish + Annual Ryegrass + Turnip, 5) Alfalfa + Annual Ryegrass and 6) Alfalfa + Turnip planted in late August of 2013.

For example, mono-culture alfalfa yielded significantly higher $(P<0.05)$ than alfalfa + oilseed radish, alfalfa + annual ryegrass, and alfalfa + turnip. Alfalfa planted with a combination of four different multi-species winter annual forages such as oats, oilseed radish, annual ryegrass, and turnip had the highest dry matter yield $\left(22.4 \mathrm{Mg} \mathrm{ha}^{-1}\right)$ of alfalfa in 2014 . In contrast, alfalfa planted with annual ryegrass had the lowest dry matter yield (12.1 Mg $\left.\mathrm{ha}^{-1}\right)$. Although it is not quite certain why dry matter yield of alfalfa planted with annual ryegrass was the lowest as compared with other treatments, annual ryegrass might have had higher interspecies competition with alfalfa. Also, annual ryegrass overwinters unlike other cover crops used in this study and might have competed with alfalfa for soil moisture.

Dry matter yield of alfalfa in $2^{\text {nd }}$ production year 2015 was similar to alfalfa + oats and alfalfa + oats + oilseed radish + annual ryegrass + turnip or significantly higher than alfalfa planted with annual ryegrass, oilseed radish, and turnip together (Table 2). Unlike the first production year 2014, alfalfa planted with a combination of oats, oilseed radish, annual ryegrass and turnip had similar yield to mono-culture of alfalfa and alfalfa planted with oats. As shown in 
the first production year, 2014, alfalfa planted with annual ryegrass in late summer of 2013 had significantly lower alfalfa yield than other treatments. This indicates that a dry matter yield reduction of alfalfa planted with annual ryegrass in the second production year couldn't recover from lower alfalfa yield in the first production year showing some negative residual effect. It is, however not clear what caused the lower yield of alfalfa when planted with annual ryegrass. Among the cover crop treatments, alfalfa planted with a combination of oats, oilseed radish, annual ryegrass, and turnip showed a drastic yield reduction as compared with other treatments. The biggest yield increase by 2.2 dry matter ton per acre occurred in alfalfa planted with oilseed radish and it is however, not certain what caused this yield improvement in the second production year. Based on two year of data in 2014 and 2015, the highest alfalfa yield occurred when alfalfa was planted with a combination of oats, oilseed radish, annual ryegrass, and turnip. This treatment had significantly higher dry matter yield than other cover crop treatments (Table 2). The lowest dry matter yield of alfalfa occurred when alfalfa was planted with annual ryegrass. Alfalfa monoculture yielded similar to alfalfa planted with oats but significantly higher than alfalfa planted with oilseed radish, annual ryegrass, and turnip, respectively. These trends were very similar to those in both first and second production years.

The mean response for nutritive values to cover crop treatments in 2014 is shown in Tables 3. Mono-culture alfalfa treatment had no difference in crude protein, ADF, and NDF when compared to other treatments except alfalfa planted with annual ryegrass. On average over the cuttings in 2014, planting alfalfa with annual ryegrass had significantly lower crude protein contents, higher acid detergent fiber and neutral detergent fiber contents than other cover crop treatments. Nutritive values of alfalfa are generally affected by stage of maturity, cutting frequency, and harvest management (Brink and Marten, 1989; Brink et al., 2010; Kallenbach et al., 2002; Kust and Smith, 1961; Moyer et al., 1999) but nutritive values of alfalfa were also affected by cover crop tested in this study. It's not certain why alfalfa planted with annual ryegrass had the lowest nutritive values as compared to other cover crop treatments. No significant differences in $\mathrm{CP}, \mathrm{ADF}$, and NDF were found when comparing alfalfa monoculture with alfalfa + oats, alfalfa + oilseed radish, alfalfa + oats + oilseed radish + annual ryegrass + turnip, and alfalfa + turnip treatments. This indicates that planting alfalfa with cover crops except annual ryegrass did not affect nutritive values of alfalfa. When considering both dry matter and nutritive values of alfalfa, planting alfalfa with cover crops could be desirable practice since the cover crops might return some organic matter and nutrients to alfalfa after they die when compared with alfalfa monoculture. Potentially, planting alfalfa with cover crops might reduce some autotoxicity issue when alfalfa needs to be planted right after alfalfa is terminated. 


\section{Al Macrothink}

Table 3. Effects of Alfalfa Planted with Cover Crop Effects on Nutritive Values (\%) of Alfalfa.

\begin{tabular}{|c|r|r|r|}
\hline \multicolumn{4}{|c|}{ Nutritive Values (\%) } \\
\hline Treatments & CP & ADF & NDF \\
\hline 1 & $20.5 \mathrm{a}$ & $18.6 \mathrm{a}$ & $22.0 \mathrm{a}$ \\
\hline 2 & $20.4 \mathrm{a}$ & $18.9 \mathrm{a}$ & $22.3 \mathrm{a}$ \\
\hline 3 & $20.8 \mathrm{a}$ & $17.9 \mathrm{a}$ & $21.8 \mathrm{a}$ \\
\hline 4 & $19.4 \mathrm{a}$ & $18.8 \mathrm{a}$ & $22.3 \mathrm{a}$ \\
\hline 6 & $20.4 \mathrm{a}$ & $17.4 \mathrm{a}$ & $21.6 \mathrm{a}$ \\
\hline 5 & $15.3 \mathrm{~b}$ & $21.1 \mathrm{~b}$ & $24.5 \mathrm{~b}$ \\
\hline
\end{tabular}

$\uparrow \mathrm{CP}$; crude protein, ADF; acid detergent fiber, and NDF; neutral detergent fiber

₹ Lower case letter within the same row denote statistical differences between cutting intervals $(\alpha=0.05)$.

II Treatments: 1) Alfalfa, 2) Alfalfa + Oats, 3) Alfalfa + Oilseed Radish, 4) Alfalfa + Oats + Oilseed Radish + Annual Ryegrass + Turnip, 5) Alfalfa + Annual Ryegrass and 6) Alfalfa + Turnip planted in late August of 2013.

\section{Conclusion and Suggestion}

In conclusion, when considering both dry matter and nutritive values of alfalfa, planting alfalfa with cover crops generally could be compatible or better practice than planting alfalfa monoculture. Planting alfalfa with 3 multi-species of cover crops (alfalfa + oats + oilseed radish + annual ryegrass + turnip) resulted in higher yield than both alfalfa monoculture and alfalfa-cover crop binary mixtures. Further research is needed to assess what caused higher alfalfa yield when alfalfa was planted with multi-species of cover crops (i.e., root systems and soil moisture) than alfalfa monoculture or alfalfa-cover crop binary mixture. 


\section{References}

Brink, G., \& Marten, G. (1989). Harvest management of alfalfa-nutrient yield vs forage quality and relationship to persistence. J. Prod. Agric. 2, 32-36.

https://doi.org/10.2134/jpa1989.0032

Brink, G., Hall, M., Shewmaker, G., Undersander, D., Martin, N., \& Walgenbach, R. (2010). Changes in alfalfa yield and nutritive value within individual harvest periods. Agron. J., 102, 1274-1282. https://doi.org/10.2134/agronj2010.0080

Dixon, P., Cash, D., Kincheloe, J., \& Tanner, J. (2005). Establishing a successful alfalfa crop. Montana State University Extension Service. MT 200504 AG C-13.

Kallenbach, R., Nelson, C., \& Coutts, J. (2002). Yield, quality, and persistence of grazingand hay-type alfalfa under three harvest frequencies. Agron. J., 94, 1094-1103.

https://doi.org/10.2134/agronj2002.1094

Komatsuzaki, M., \& Wagger, M. G. (2015). Nitrogen recovery by cover crops in relation to time of planting and growth termination. Journal of Soil and Water Conservation. 70, 385-398. https://doi.org/10.2489/jswc.70.6.385

Kust, C. A., \& Smith, D. (1961). Influence of harvest management on the level of carbohydrate reserves, longevity of stands, and yields of hay and protein from Vernal alfalfa. Crop Sci., 1, 267-269. https://doi.org/10.2135/cropsci1961.0011183X000100040011x

Lanini, W., Orloff, S., Vargas, R., \& Orr, J. (1992). Using oats as a companion crop in establishing alfalfa. California Agriculture. 46(4), 25-27.

Mantino, A., Ragaglini, G., Nasso, N., Tozzini, C., Taccini, F., \& Bonari, E. (2016). Alfalfa (Medicago sativa L.) overseeding on mature switchgrass (Panicum virgatum L.) stand, biomass yield and nutritive value after the establishment year. Ital. J. Agron., 11, 143-148. https://doi.org/10.4081/ija.2016.747

Masilionyte, L., Maiksteniene, S., Kriauciuniene, Z., Jablonskyte-Rasce, D., Zou, L., Sarauskis, E. (2017). Effect of cover crops in smothering weeds and volunteer plants in alternative farming systems. Crop Protection., 91, 74-81.

https://doi.org/10.1016/j.cropro.2016.09.016

Mitchell, J., Shrestha, A., Mathesius, K., Scow, K., Southard, R., Haney, R., Schmidt, R., Munk, D., \& Horwath, W. (2017). Cover cropping and no-tillage improve soil health in an arid irrigated cropping system in California's San Joaquin Valley, USA. Soil and Tillage Research, 165, 325-335. https://doi.org/10.1016/j.still.2016.09.001

Moyer, J. R., Fraser, J., Rode, L. M., \& Topinka, A. K. (1999). Effects of growth stage-based alfalfa harvest on weed encroachment and resultant quality. Can. J. Plant Sci. 79, 243-247. https://doi.org/10.4141/P98-059

Sainju, U. M., \& Singh, B. P. (2015). Cover crop effects on soil carbon and nitrogen under bioenergy sorghum crops. Journal of Soil and Water Conservation, 70, 410-417. 


\section{Macrothink}

Journal of Agricultural Studies

ISSN 2166-0379

2017, Vol. 5, No. 2

https://doi.org/10.2489/jswc.70.6.410

Sheaffer, C., \& Marten, G. (1990). Alfalfa cutting frequency and date of fall cutting. J. Prod. Agric., 3, 486-491. https://doi.org/10.2134/jpa1990.0486

Steele, R., \& Torrie, J. (1980). Principles and procedures of statistics: A biometrical approach. 2nd ed. McGraw-Hill. New York.

Thorup-Kristensen, K., \& Rasmussen, C. R. (2015). Identifying new deep-rooted plant species suitable as undersown nitrogen catch crops. Journal of Soil and Water Conservation, 70, 399-409. https://doi.org/10.2489/jswc.70.6.399

Undersander, D., Cosgrove, D., Cullen, E., Grau, C., Rice, M., Renz, M., Sheaffer, C., Shewmaker, G., \& Sulc, M. (2010). Alfalfa Management Guide. American Society of Agronomy. ISBN:978-0-89118-179-8.

USDA Census of Agriculture. (2012). http://www.agcensus.usda.gov/Publications/2012.

\section{Copyright Disclaimer}

Copyright for this article is retained by the author(s), with first publication rights granted to the journal.

This is an open-access article distributed under the terms and conditions of the Creative Commons Attribution license (http://creativecommons.org/licenses/by/4.0/). 